\title{
Fire Behaviour of Cross-Laminated Solid Timber Panels
}

\author{
ANDREA FRANGI, MARIO FONTANA, MARKUS KNOBLOCH and GIOVANNA BOCHICCHIO ${ }^{1}$ \\ Institute of Structural Engineering, ETH Zurich \\ IBK, HIL D35.1, Wolfang-Pauli-Strasse 15 \\ 8093 Zurich, Switzerland \\ ${ }^{1}$ Trees and Timber Institute CNR-IVALSA \\ 38010 San Michele all'Adige (TN), Italy
}

\section{ABSTRACT}

Cross-laminated solid timber panels represent an interesting technical and economical product for modern timber structures. The use of large prefabricated cross-laminated solid timber panels for load-bearing wall and floor assemblies has become increasingly popular in particular for residential timber buildings. The fire behaviour of cross-laminated solid timber panels has been experimentally and numerically studied during two different ongoing research projects carried out at the Institute of Structural Engineering of ETH Zurich, Switzerland and the Trees and Timber Institute CNR-IVALSA in Trento, Italy. The paper presents the main results of the experimental and numerical analyses. Particular attention is given to the comparison of the fire behaviour of cross-laminated solid timber panels with homogeneous timber panels.

The results of the analysis have shown that the fire behaviour of cross-laminated solid timber panels depends on the behaviour of the single layers. If the charred layers fall off, an increased charring rate needs to be taken into account. The same effect is observed for initially protected timber members after the fire protection has fallen off. Thus the fire behaviour of cross-laminated solid timber panels can be strongly influenced by the thickness and the number of layers. Further vertical structural members (walls) may show a better fire behaviour in comparison to horizontal members (slabs).

KEYWORDS: cross-laminated solid timber panels, fire tests, fire behaviour, notional charring rate, onedimensional charring, FE-thermal analysis, modeling, structural response, structural design

\section{NOMENCLATURE LISTING}

$d_{\text {char }}$
$d_{\text {char }, n}$
$d$
$t$
$t_{a}$
$t_{c h}$
$t_{f}$
$T$

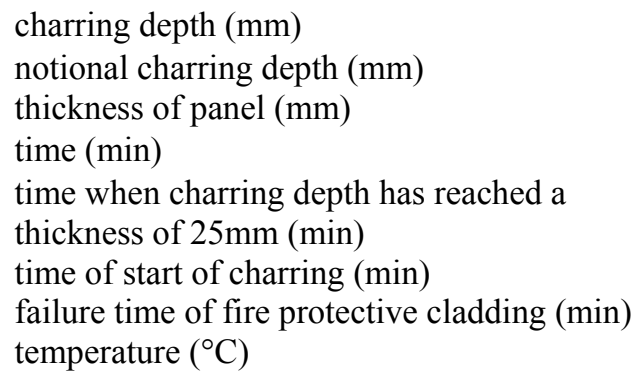
Greek
$\alpha_{c} \quad$ coefficient of heat transfer $\left(\mathrm{W} / \mathrm{m}^{2} \mathrm{~K}\right)$
$\beta_{0}$ one-dimensional charring rate $(\mathrm{mm} / \mathrm{min})$
$\beta_{n} \quad$ notional charring rate $(\mathrm{mm} / \mathrm{min})$
$\varepsilon_{\text {res }}$ resultant emissivity by radiation (-)

\section{INTRODUCTION}

The construction industry has drawn attention to new construction methods based on building systems. Wood particularly fits the requirements of the idea "built with system" because of its easy manufacturing possibility. An example of a successful construction system are large prefabricated cross-laminated solid timber panels (CLSTP) for load bearing wall and floor assemblies. Cross-laminated solid timber panels have become increasingly popular not only for residential but also for office, retail and industrial buildings in particular in Austria and Italy. CLSTP are produced in the factory according to the structural drawings taking into account door/window/stair openings, transported from the factory directly to the site and then joined on site with simple and rapid connections. Insulation and facade elements can be connected easily to the timber panels. Unlike light timber frame constructions, where single timber studs are responsible for the transfer of the vertical loads, the use of large solid timber panels allow the transfer of high vertical loads and guarantee a high building stiffness and robustness. Other main advantages of this new building system are an excellent thermal insulation and air tightness. The use of large solid timber panels is also favorable 
in case of fire, as the risk of fire spread through void cavities is reduced in comparison to light timber frame constructions. However, large solid timber panels increase the fire load in the room.

Cross-laminated solid timber panels are produced from industrially dried spruce boards which are stacked crosswise and glued together over their entire surface. Depending on the purpose and static requirement, CLSTP are available with 3, 5, 7 or more board layers. The width of the single boards usually varies between 80 and $240 \mathrm{~mm}$, the thickness between 10 and $35 \mathrm{~mm}$. The cross-section is symmetrical. Each single board is visually or machine graded and can be jointed using finger joints. The size and form of cross-laminated solid timber panels is limited by production, transportation and erection possibilities. Figure 1 shows an example of cross-laminated solid timber panel [1].

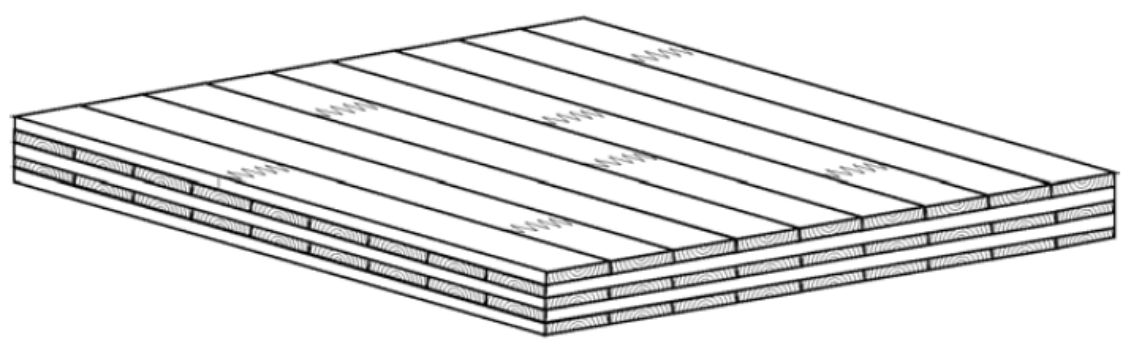

Fig. 1. Example of cross-laminated solid timber panel [1].

Combustible building materials like timber burn on their surface, release energy and thus contribute to fire propagation and the development of smoke in case of fire. The main precondition for the use of wood for buildings is adequate fire safety. Fire safety is an important contribution to feeling comfortable and an important criterion for the choice of material in particular for residential buildings. Since the 90-ties, many research projects have focused on the fire behaviour of timber structures worldwide [2,3]. The fire behaviour of cross-laminated solid timber panels has been experimentally and numerically studied during two different ongoing research projects carried out at the Institute of Structural Engineering of ETH Zurich, Switzerland and the Trees and Timber Institute CNR-IVALSA in Trento, Italy. The paper presents the main results of the experimental and numerical analyses. Particular attention is given to the comparison of the fire behaviour of cross-laminated solid timber panels with homogeneous timber panels.

\section{CHARRING OF TIMBER}

Timber is a combustible material and thus differs from most other commonly used structural building materials. When sufficient heat is applied to wood, a process of thermal degradation (pyrolysis) takes place producing combustible gases, accompanied by a loss in mass. A charred layer is then formed on the fireexposed surfaces and the char layer grows in thickness as the fire progresses, reducing the cross-sectional dimensions of the timber member. The char layer is a good insulator and protects the remaining uncharred residual cross-section against heat. For timber surfaces unprotected throughout the time of fire exposure, the charring rate can be assumed constant with time [4]. As a basic value, the one-dimensional charring rate $\beta_{0}$ is usually taken as the value observed for one-dimensional heat transfer under ISO-fire exposure in a semi-infinite timber slab. At the corners of the cross-section increased charring occurs, leading to corner rounding. In order to simplify the calculation of cross-sectional properties (area, section modulus and second moment of area) by assuming an equivalent rectangular residual cross-section, a notional charring rate $\beta_{\mathrm{n}}$ is used so that it implicitly includes the effect of corner rounding and gives approximately the same results. Table 1 gives the notional charring rate $\beta_{\mathrm{n}}$ and the charring rate $\beta_{0}$ for one-dimensional charring according to EN 1995-1-2 [5]. As timber panels are usually exposed to fire on one side, only the onedimensional charring rate $\beta_{0}$ is given in Table 1 . 
Table 1. Notional charring rate $\beta_{\mathrm{n}}$ and charring rate $\beta_{0}$ for one-dimensional charring according to EN 1995-1-2 [5].

\begin{tabular}{|l|c|c|}
\hline Material & $\beta_{\mathbf{0}}[\mathrm{mm} / \mathbf{m i n}]$ & $\beta_{\mathbf{n}}[\mathrm{mm} / \mathbf{m i n}]$ \\
\hline Softwood and beech & & \\
Glued laminated timber with a characteristic density $\geq 290 \mathrm{~kg} / \mathrm{m}^{3}$ & 0.65 & 0.7 \\
Solid timber with a characteristic density $\geq 290 \mathrm{~kg} / \mathrm{m}^{3}$ & 0.65 & 0.8 \\
\hline Panels & & - \\
Wood panelling & 0.9 & - \\
Plywood & 1.0 & - \\
Wood-based panels other than plywood & 0.9 & \\
\hline
\end{tabular}

For protected timber surfaces different charring rates should be applied during different phases of fire exposure [6]. Figure 2 gives the simplified model adopted by EN 1995-1-2 when start of charring $t_{c h}$ occurs at the same time as the failure $t_{\mathrm{f}}$ of the cladding. Phase $2 \mathrm{a}$ describes the increased charring of timber after the claddings have fallen off. EN 1995-1-2 assumed that charring takes place at double the rate of initially unprotected surfaces. The main physical reasons for the increased charring rate observed after failure of the cladding is that, at that time, the fire temperature is already at a high level while no protective char layer exists to reduce the effect of the temperature. The protection provided by the char layer is assumed to grow progressively until its thickness has reached $25 \mathrm{~mm}$. Then the charring rate decreases to the value for initially unprotected surfaces. For simplicity, the $25 \mathrm{~mm}$ criterion is adopted for both the one-dimensional and notional charring depth. The simplified model can be used for protective claddings made of woodbased panels or wood paneling and common regular gypsum plasterboards [7].

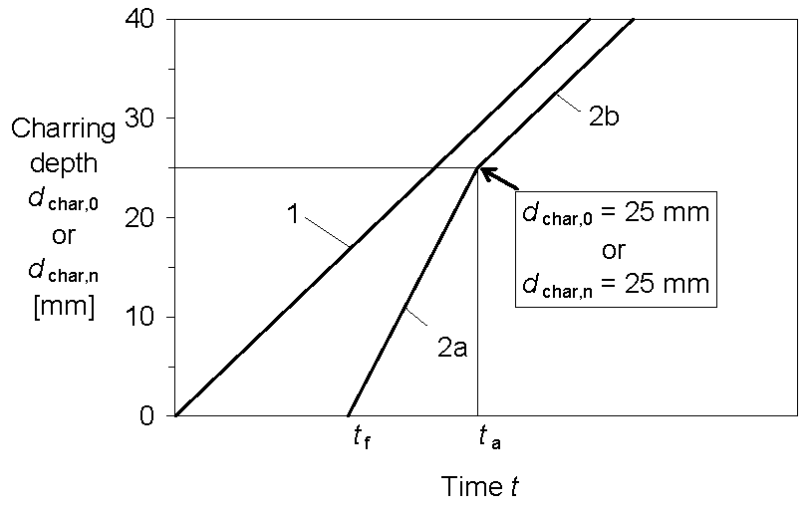

Key:

1 Relationship for initially unprotected members for charring rate $\beta_{0}$ and $\beta_{n}$

2 Relationship for initially protected members where charring $t_{c h}$ starts at the same time as the failure of protection $\mathrm{t}_{\mathrm{f}}$ : 2a After protection has fallen off charring increased at double rate $\beta_{0}$ and $\beta_{n}$ 2b After char depth exceeds $25 \mathrm{~mm}$ charring rate reduces to $\beta_{0}$ and $\beta_{\mathrm{n}}$

Fig. 2. General description of charring for initially protected timber surfaces according to EN 1995-1-2 [5] when start of charring $t_{c h}$ occurs at the same time as the failure (i.e. fall off) of the fire protective cladding $t_{f}$ (line 2). Line 1 is for initially unprotected timber surfaces.

A few experimental investigations are available on the fire behaviour of cross-laminated solid timber panels. In particular the basic question whether the fire behaviour of CLSTP is similar to homogenous timber panels has not been yet systematically analysed. The fire behaviour of cross-laminated solid timber panels is characterized by the behaviour of the single layers. Following two boundary situations can be assumed:

- if the charred layers remain in place, the charcoal protects the remaining uncharred layers of the crosslaminated timber solid panels against heat. In this case a fire behaviour similar to homogenous timber panels can be expected.

- if the charred layers immediately fall off after charring, the fire protective function of the charcoal is lost. After the charred layers have fallen off, an increased charring is expected due to the increased fire temperature. This phenomenon is similar to the increased charring observed for protected timber surfaces after failure of the fire protective cladding as previously explained (see Fig. 2). The position of the panel (horizontal for slabs, vertical for walls), the thickness of the layers as well as the behaviour of the 
bonding adhesive at high temperature can influence the falling of the charred layers and thus play an important role in the evaluation of the fire behaviour of cross-laminated solid timber panels.

It can be expected that CLSTP with thick layers should show a better fire behaviour in comparison to CLSTP with thin layers. In the case of very thick layers, cross-laminated solid timber panels should behave similar to homogenous timber panels and therefore the one-dimensional charring rate of $0.65 \mathrm{~mm} / \mathrm{min}$ according to EN 1995-1-2 can be assumed. In the case of very thin layers, cross-laminated solid timber panels should behave more like plywood. The fire behaviour of plywood is characterised by a pronounced falling of the charred veneers [8]. For this reason, the one-dimensional charring rate assumed for plywood according to EN 1995-1-2 is $1.0 \mathrm{~mm} / \mathrm{min}$ and thus higher than for other wood based-panels and solid timber (see Table 1). In comparison to homogenous timber panels, cross-laminated solid timber panels present longitudinal and transverse joints between the timber boards, that can lead locally to increased charring. As the joint gaps are very small and further the joints are backed by other timber boards, the influence on the global fire behaviour of cross-laminated solid timber panels should be relative small. This influence can be taken into account by using a higher notional charring rate $\beta_{\mathrm{n}}$ than the one-dimensional charring rate $\beta_{0}$.

\section{FE-THERMAL ANALYSIS}

For the calculation of charring of cross-laminated solid timber panels subjected to ISO-fire exposure a FEthermal analysis was conducted using ANSYS. The heat transfer to the surface of the member was calculated using temperature-independent constant values according to EN 1991-1-2 [9] for the resultant emissivity by radiation $\varepsilon_{\text {res }}=0.8$ and the coefficient of heat transfer by convection $\alpha_{c}=25 \mathrm{~W} / \mathrm{m}^{2} \mathrm{~K}$. Density, thermal conductivity and specific heat capacity of wood and charcoal vary as a function of the temperature. The change of moisture, i.e. the evaporation of water at a temperature of about $100^{\circ} \mathrm{C}$ was implemented into the FE-simulation as latent heat. Mass transfer of moisture into or out of the wood was neglected. In the FE-thermal analysis, charring of wood (i.e. reduction of cross-section) was taken into account by gradually changing the thermal properties of wood into those of charcoal with increasing temperature. The temperature dependent relationships for the density, specific heat and thermal conductivity of wood and charcoal were assumed according to EN 1995-1-2. The FE-model was verified with a series of fire tests [10] on spruce timber specimens exposed to ISO-fire only on one side. The specimens had a moisture content of about $12 \%$. Temperatures were measured in a depth of $6,18,30$ and $42 \mathrm{~mm}$ from the surface exposed to fire. Figure 3 shows the comparison between fire tests and FE-results for the temperatures measured in different timber depths. Experimental and numerical results are in good agreement. More details on the validation of the material properties used for the FE-thermal analysis can be found in [11].

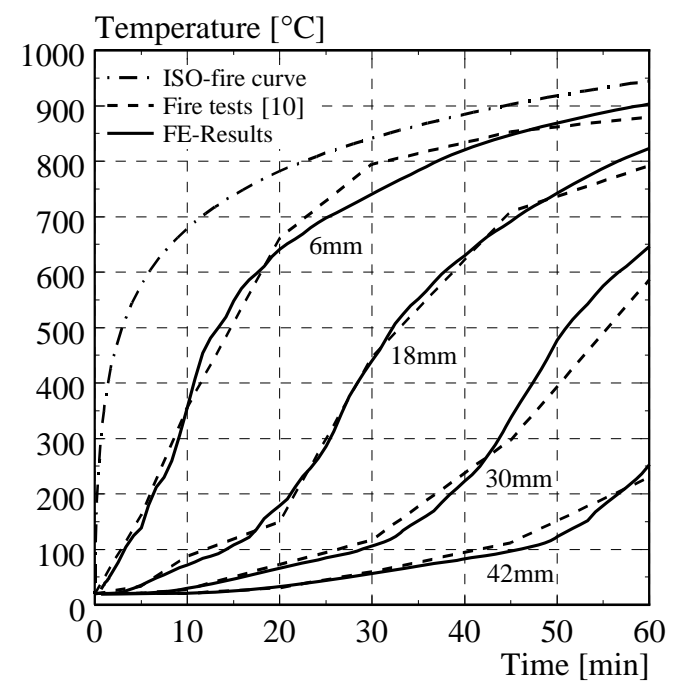

Fig. 3. Comparison of temperatures by FE-thermal analysis and fire tests [10] in different depths of timber specimens exposed to ISO-fire on one side. 
Table 2. Charring depth and charring rates $\beta_{\text {panel }}$ and $\beta_{\text {layer }}$ calculated after each layer of the cross-laminated solid timber panel is completely charred. The charring rates $\beta_{\text {panel }}$ and $\beta_{\text {layer }}$ are calculated as following:

$$
\beta_{\text {panel }}=\mathrm{d}_{\text {char }} / \mathrm{t} ; \beta_{\text {layer }}=\Delta \mathrm{d}_{\text {char,layer }} / \Delta \mathrm{t}_{\text {layer }}
$$

\begin{tabular}{|c|c|c|c|c|c|c|c|}
\hline \multicolumn{4}{|c|}{$\begin{array}{c}\text { Cross-laminated solid timber panel } \\
\text { with 5x17mm thick layers }\end{array}$} & \multicolumn{4}{c|}{$\begin{array}{c}\text { Cross-laminated solid timber panel } \\
\text { with 3x28mm thick layers }\end{array}$} \\
\hline $\begin{array}{c}\mathrm{t} \\
{[\mathrm{min}]}\end{array}$ & $\begin{array}{c}\mathrm{d}_{\mathrm{char}} \\
{[\mathrm{mm}]}\end{array}$ & $\begin{array}{c}\beta_{\text {panel }} \\
{[\mathrm{mm} / \mathrm{min}]}\end{array}$ & $\begin{array}{c}\beta_{\text {layer }} \\
{[\mathrm{mm} / \mathrm{min}]}\end{array}$ & $\begin{array}{c}\mathrm{t} \\
{[\mathrm{min}]}\end{array}$ & $\begin{array}{c}\mathrm{d}_{\text {char }} \\
{[\mathrm{mm}]}\end{array}$ & $\begin{array}{c}\beta_{\text {panel }} \\
{[\mathrm{mm} / \mathrm{min}]}\end{array}$ & $\begin{array}{c}\beta_{\text {layer }} \\
{[\mathrm{mm} / \mathrm{min}]}\end{array}$ \\
\hline 0 & 0 & 0 & 0 & 0 & 0 & 0 & 0 \\
\hline 23.7 & 17 & 0.72 & 0.72 & 40.9 & 28 & 0.69 & 0.69 \\
\hline 36.5 & 34 & 0.93 & 1.33 & 64.1 & 56 & 0.87 & 1.20 \\
\hline 46.8 & 51 & 1.09 & 1.65 & 83.0 & 84 & 1.01 & 1.48 \\
\hline 56.0 & 68 & 1.21 & 1.83 & & & & \\
\hline 64.3 & 85 & 1.32 & 2.07 & & & & \\
\hline
\end{tabular}

Figure 4 left shows the charring depth calculated for a $85 \mathrm{~mm}$ thick homogeneous timber panel and a crosslaminated solid timber panel with the same thickness consisting of 5 layers with a thickness of $17 \mathrm{~mm}$ each. Figure 4 right shows the charring depth calculated for a $84 \mathrm{~mm}$ thick homogeneous timber panel and a cross-laminated solid timber panel with the same thickness consisting of 3 layers with a thickness of $28 \mathrm{~mm}$ each. The timber elements were exposed to ISO-fire on one side. The charring depth was calculated as the position of the $300^{\circ} \mathrm{C}$ isotherm. For the cross-laminated timber solid panel it was assumed that the charcoal falls off after the layer is completely charred, i.e. when the temperature at the interface between the layers reaches $300^{\circ} \mathrm{C}$. Table 2 gives the charring rate calculated considering the whole cross-section and each single layer of the cross-laminated solid timber panel.
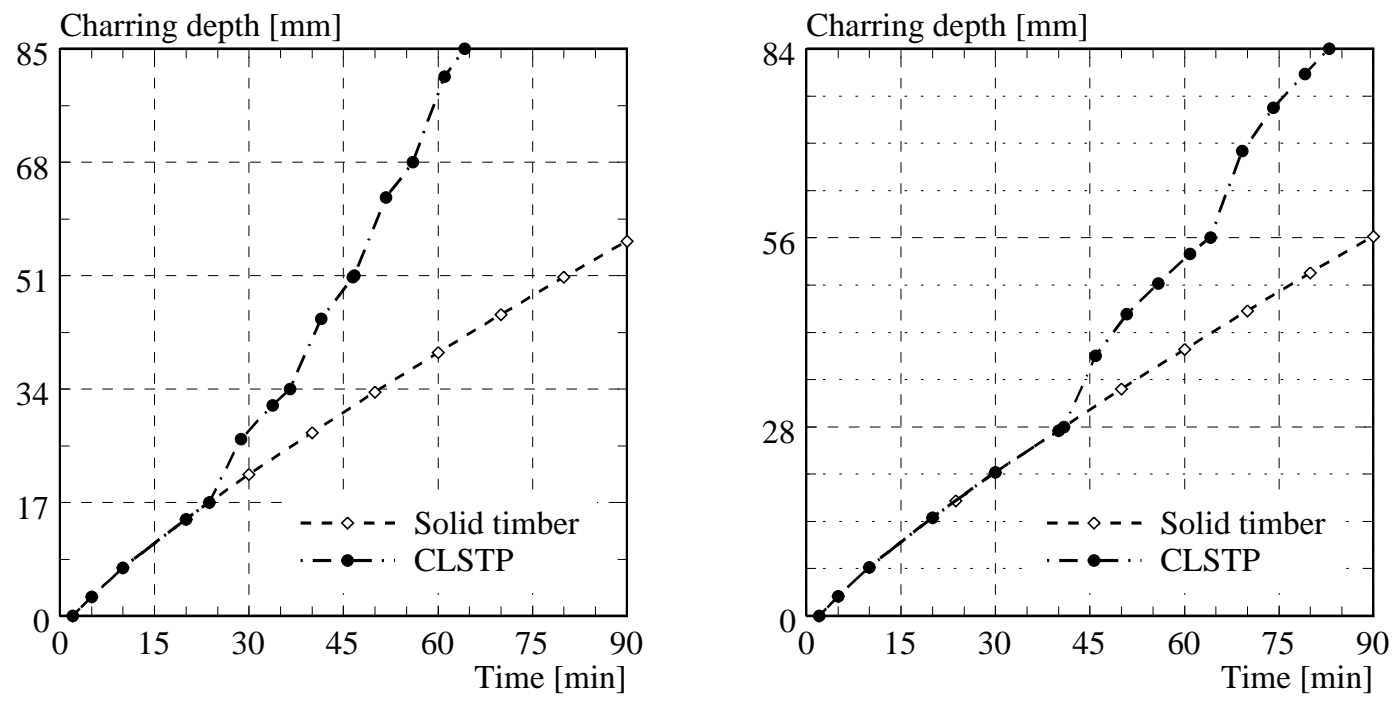

Fig. 4. Left: charring depth calculated for a $85 \mathrm{~mm}$ thick homogeneous timber panel and a cross-laminated solid timber panel with the same thickness consisting of 5 layers with a thickness of $17 \mathrm{~mm}$ each. Right: charring depth calculated for a $84 \mathrm{~mm}$ thick homogeneous timber panel and a cross-laminated solid timber panel with the same thickness consisting of 3 layers with a thickness of $28 \mathrm{~mm}$ each.

From Fig. 4 it can be seen that the charring depth of the cross-laminated solid timber panels is the same as for the homogeneous timber panels until the first layer of the CLSTP $(17 \mathrm{~mm}$ in Fig. 4 left and $28 \mathrm{~mm}$ in Fig. 4 right) is completely charred. At that time it is assumed that the charcoal of the first layer falls off leading to an increased charring of the second layer compared to the homogeneous timber panel. The reason for the observed increased charring rate is that the second layer is directly exposed to high temperature while no protective char layer exists to reduce the effect of the temperature. As the charcoal of the second layer grows in thickness, the charring rate starts reducing to the value of the homogeneous timber panel, until the second layer is also completely charred. At that time, the charcoal of the second 
layer falls off leading to an increased charring of the third layer compared to the homogeneous timber panel. This phenomenon is observed after each charred layer has fallen off.

The FE-thermal analysis shows that the charring rate of cross-laminated solid timber panels is not constant as the fire progresses. After the protective charcoal of a layer has fallen off, an increased charring rate needs to be taken into account. Further it can be seen that the charring rate also depends on the time when the protective charcoal falls off. The later the charcoal falls off, the more the charring rate increases after falling of the protective charcoal. The reason is the increasing fire temperature as the fire progresses. The FE-thermal analysis also shows the large influence of the thickness of the single layers on the global fire behaviour of cross-laminated solid timber panels. The $85 \mathrm{~mm}$ thick CLSTP consisting of 5 layers with 17 $\mathrm{mm}$ thickness each is completely charred after 64 minutes; this corresponds to an average charring rate of about $1.3 \mathrm{~mm} / \mathrm{min}$ (see Table 2). On the other hand, the $84 \mathrm{~mm}$ thick CLSTP consisting of 3 layers with 28 $\mathrm{mm}$ thickness is completely charred after 83 minutes; this corresponds to an average charring rate of about $1.0 \mathrm{~mm} / \mathrm{min}$ (see Table 2). Thus, the fire behaviour of CLSTP strongly depends on the number and thickness of the single layers in the case that the fire protective charcoal falls off after each layer is completely charred.

\section{EXPERIMENTEAL ANALYSIS}

\section{Small-scale fire tests on timber panels (ETH Zurich)}

During an ongoing research project carried out at the Institute of Structural Engineering of ETH Zurich the fire behaviour of timber panels and gypsum plasterboards has been analysed with an extensive fire testing program [12]. All fire tests were performed with unloaded specimens at the Swiss Federal Laboratories for Materials Testing and Research (EMPA) in Dubendorf using ISO-fire exposure. The tests were carried out on the small furnace with the dimensions of $1.0 \times 0.8 \mathrm{~m}$. The fire test V12 permitted the direct comparison between a $54 \mathrm{~mm}$ thick homogeneous timber panel and a 3-layered timber panel with the same total thickness (with $3 \times 18 \mathrm{~mm}$ thick layers). The fire test V13 was similar to fire test V12, however two homogeneous timber panels as well as two 3-layered timber panels (with $3 \times 9 \mathrm{~mm}$ thick layers) were tested. Figure 6 shows the geometry of both test specimens.

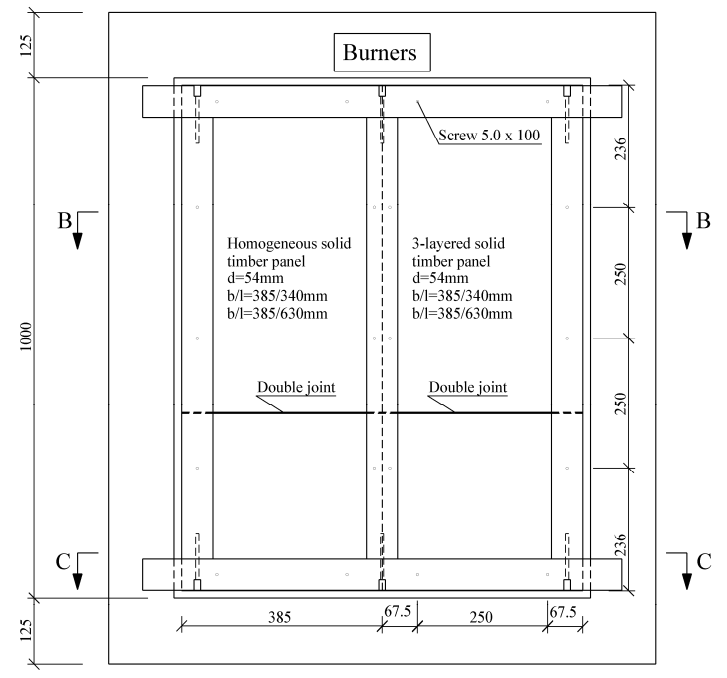

$\underline{\text { Section B-B }}$

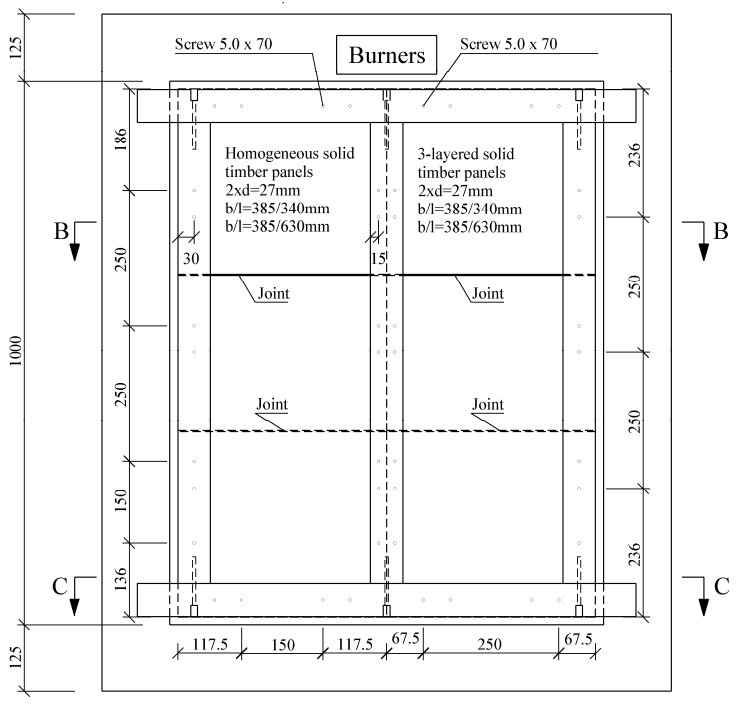

$\underline{\text { Section B-B }}$
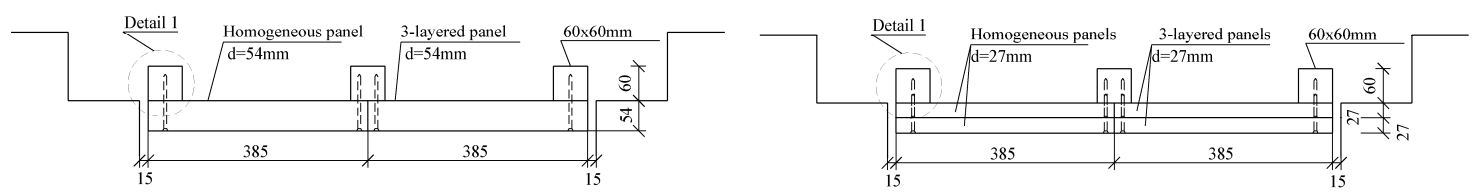

Fig. 5. Plan and cross-section of the test specimens V12 (left) and V13 (right). 
The test specimens consisted of timber panels made of spruce with a mean density of $420 \mathrm{~kg} / \mathrm{m}^{3}$ and an average moisture content of $11 \%$. The adhesive used for bonding of the 3-layered timber panels was a polyurethane adhesive. During the fire test V12, the fire exposed $18 \mathrm{~mm}$ thick charred layer of the 3layered timber panel (with total thickness of $54 \mathrm{~mm}$ ) started falling off after about 26.5 minutes. After about 28 minutes the fire exposed charred layer has completely fallen off. According to the FE-thermal analysis the temperature at the interface between the first und second layer reaches $300^{\circ} \mathrm{C}$ after about 25 minutes (see Fig. 7 left), i.e. at that time it can be assumed that the first layer is completely charred. Thus the charcoal of the first layer started falling off almost immediately after charring. Falling of charred layers of the 3-layered timber panels was also clearly observed during the fire test V13.

Fire test V12
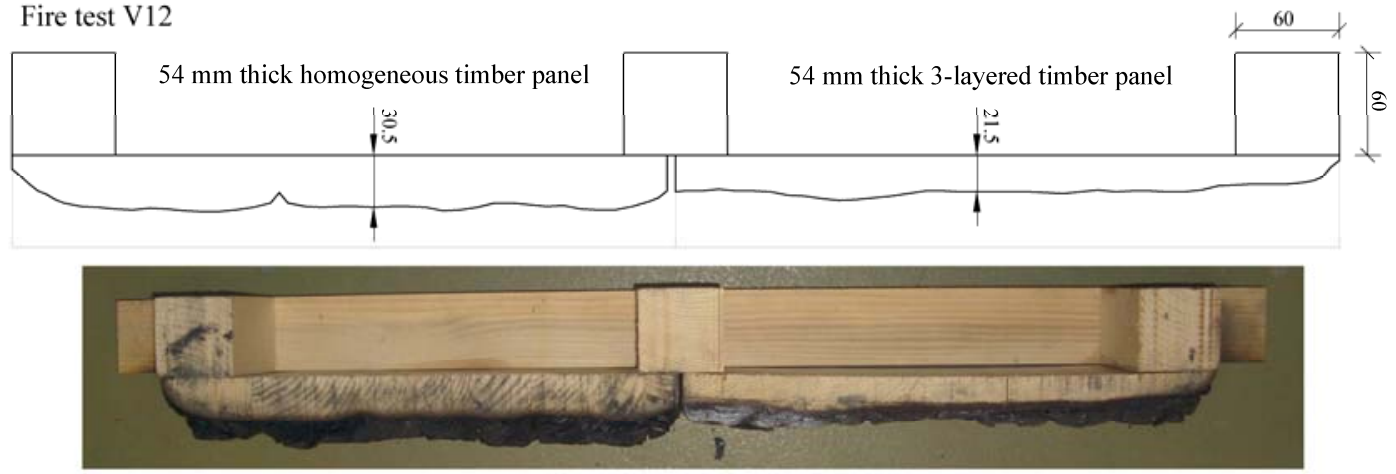

Fire test V13

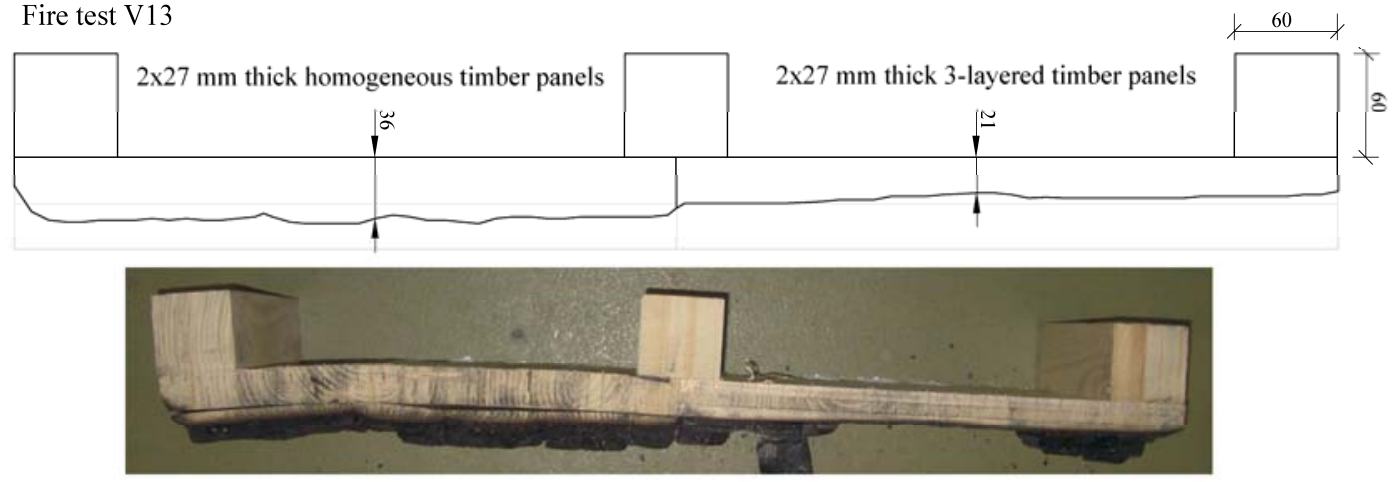

Fig. 6. Residual cross-section of the test specimens V12 and V13 after the fire tests. The fire test V12 had a duration of 38 minutes, the duration of the fire test V13 was 28 minutes.

Table 3. Measured charring depth and charring rates for the fire tests V12 and V13 with homogeneous timber plates and cross-laminated timber panels consisting of 3 layers.

\begin{tabular}{|c|c|c|c|c|c|}
\hline Test & $\begin{array}{l}\text { Fire time } \\
\text { [min] }\end{array}$ & Panel & $\begin{array}{l}\Delta \mathrm{t}_{\text {panel }} \\
{[\mathrm{min}]}\end{array}$ & $\begin{array}{c}\mathrm{d}_{\text {char,panel }} \\
{[\mathrm{mm}]}\end{array}$ & $\begin{array}{c}\beta_{\text {panel }} \\
{[\mathrm{mm} / \mathrm{min}]}\end{array}$ \\
\hline \multirow{2}{*}{ V12 } & \multirow{2}{*}{38} & $\begin{array}{c}54 \mathrm{~mm} \text { thick } \\
\text { homogeneous timber panel }\end{array}$ & 38 & 25.0 & 0.66 \\
\hline & & $\begin{array}{c}54 \mathrm{~mm} \text { thick } \\
\text { 3-layered timber panel }\end{array}$ & 38 & 32.0 & 0.84 \\
\hline \multirow{2}{*}{ V13 } & \multirow{2}{*}{28} & $\begin{array}{c}2 \times 27 \mathrm{~mm} \text { thick } \\
\text { homogeneous timber panels }\end{array}$ & $\begin{array}{l}\text { 1. panel: } 28 \\
\text { 2. panel: - }\end{array}$ & $\begin{array}{l}\text { 1. panel: } 17.3 \\
\text { 2. panel: - }\end{array}$ & $\begin{array}{l}\text { 1. panel: } 0.62 \\
\text { 2. panel: - }\end{array}$ \\
\hline & & $\begin{array}{c}2 \times 27 \mathrm{~mm} \text { thick } \\
\text { 3-layered timber panels }\end{array}$ & $\begin{array}{l}\text { 1. panel: } 25.5 \\
\text { 2. panel: } 2.5\end{array}$ & $\begin{array}{l}\text { 1. panel: } 27.0 \\
\text { 2. panel: } 3.5\end{array}$ & $\begin{array}{l}\text { 1. panel: } 1.05 \\
\text { 2. panel: } 1.40\end{array}$ \\
\hline
\end{tabular}

The fire test V12 was stopped after 38 minutes, fire test V13 after 28 minutes, in both cases due to failure of the separating function at the joints. Figure 6 shows the typical residual cross-sections of both specimens after the fire tests. Table 3 gives the measured average charring depths and the resulting charring rates of the timber panels tested. The charring rate of the first fire exposed 3-layered timber panel of test V13 was 
calculated using temperature measurements. It was assumed that the fire exposed 3-layered timber panel was completely charred when the temperature of $300^{\circ} \mathrm{C}$ was measured at the interface between the first and second panel. The time difference $\Delta \mathrm{t}_{\text {panel }}$ given in Table 3 represents the time of fire exposure of each panel. Figure 6 and Table 3 show that the measured charring depth of the 3-layered solid timber panel is higher than for the homogeneous timber panel. The resulting average charring rate of the homogeneous timber panels was $0.66 \mathrm{~mm} / \mathrm{min}$ (fire test V12) and $0.62 \mathrm{~mm} / \mathrm{min}$ (fire test V13). The measured charring rates agree well with the one-dimensional charring rate of $0.65 \mathrm{~mm} / \mathrm{min}$ for solid timber according to EN 19951-2. The resulting average charring rate of the 3-layered timber panels was $0.84 \mathrm{~mm} / \mathrm{min}$ (fire test V12) and $1.05 \mathrm{~mm} / \mathrm{min}$ (fire exposed panel of fire test V13).
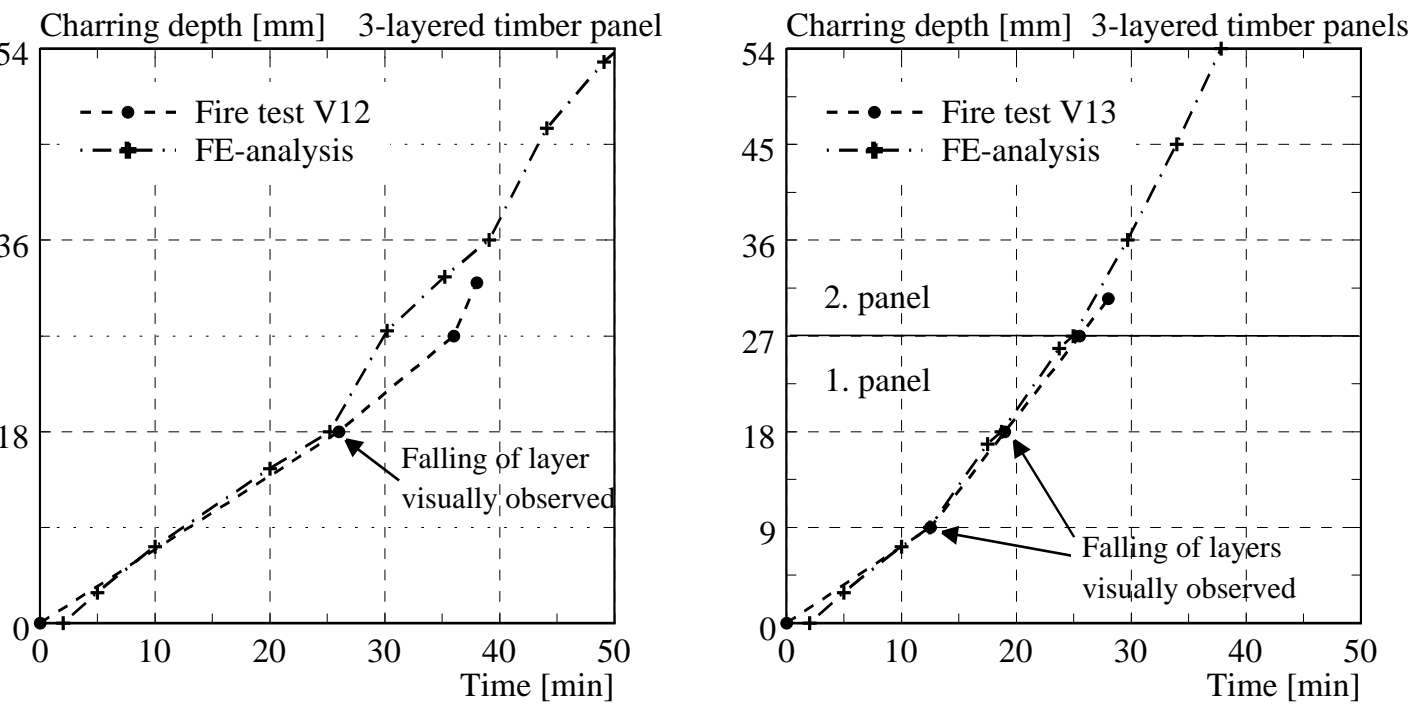

Fig. 7. Comparison between measured and calculated charring depth for the $54 \mathrm{~mm}$ thick 3-layered crosslaminated timber panel of fire test V12 (left) and the $2 \times 27 \mathrm{~mm}$ thick 3-layered cross-laminated timber panels of fire test V13 (right).

Figure 7 compares the measured charring depth of the 3-layered timber panels with the charring depth calculated according the FE-thermal analysis. The charring depth was calculated as the position of the $300^{\circ} \mathrm{C}$ isotherm. Further, for the FE-thermal analysis it was assumed that the charcoal falls off after the layer is completely charred, i.e. when the temperature at the interface between the layers reaches $300^{\circ} \mathrm{C}$. There is a good agreement between the fire test V13 ( $2 \times 27 \mathrm{~mm}$ thick 3-layered timber panels) and the FEthermal analysis, confirming the expected increased charring after each charred layer has fallen off. For the fire test V12 the FE-thermal analysis overestimated the calculated charring depth of the $54 \mathrm{~mm}$ thick 3layered timber panel after the first fire exposed $18 \mathrm{~mm}$ thick layer was completely charred. The reason is that the second layer was protected by the remaining charcoal of the first layer during more time than assumed in the FE-thermal analysis. However, as the fire progresses, the charcoal of the first layer fell off, leading to an increased charring of the second layer. At the end of the fire test the difference of the measured charring depth between fire test and FE-thermal analysis was small.

The fire tests showed that the measured charring rate of 3-layered timber panels was higher than for homogeneous timber panels, as the charcoal of the charred layers fell off earlier than in the case of homogeneous timber panels. Further the timber panel with $3 \times 9 \mathrm{~mm}$ thick layers showed a higher charring rate than the timber panel with $3 \times 18 \mathrm{~mm}$ thick layers, confirming that the fire behaviour of multilayer timber panels can be strongly influenced by the thickness of the layers.

\section{Large scale fire tests on slab and wall timber elements (ETH Zurich)}

The fire behaviour of hotels of modular construction in wood was experimentally studied during a recently completed research project carried out at the Institute of Structural Engineering of ETH Zurich [13]. Four large-scale fire tests on different types of light-timber frame wall assemblies were performed at EMPA's vertical furnace $(3 \times 3 \mathrm{~m})$. The walls were exposed to ISO-fire until the integrity criterion (no smoke or fume 
penetration) or the thermal insulation criterion failed. During the fire tests the temperatures on the surface and in selected locations in the walls were measured. The design of the light-timber frame wall assemblies represented the situation of two adjacent hotel modules. The room claddings consisted of $27 \mathrm{~mm}$ thick $3-$ layered timber panels (walls W1, W2 and W4) or $15 \mathrm{~mm}$ gypsum plasterboards (wall W3). The 3-layered timber panels made of spruce had a mean density of $457 \mathrm{~kg} / \mathrm{m}^{3}$ and an average moisture content of $12 \%$. The void cavities were filled with insulation made of wood fibre or rock fibre. Figure 8 shows the geometry and test set-up of the wall $\mathrm{W} 1$. The geometry of the other walls was identical to wall W1.

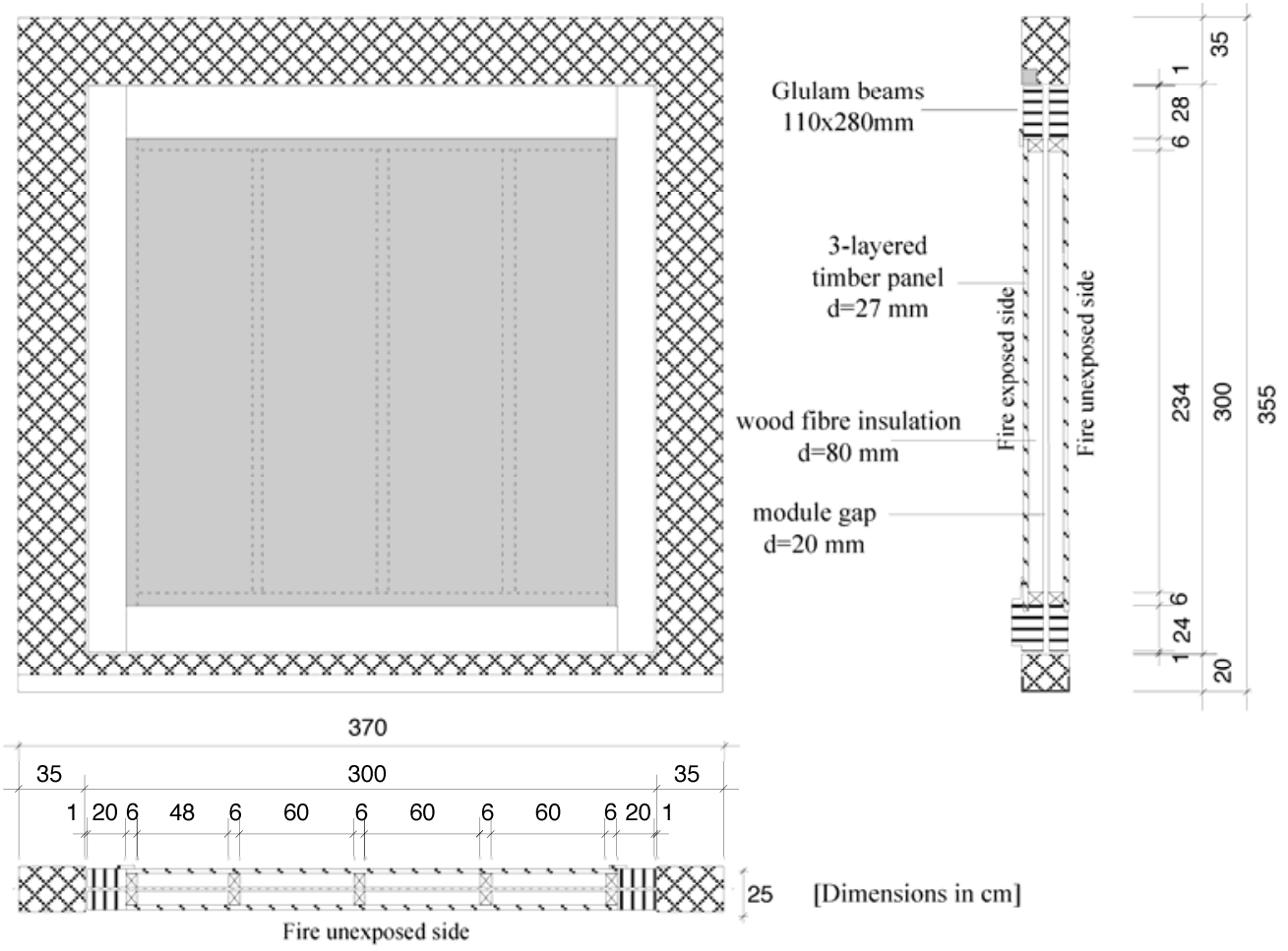

Fig. 8. Test specimen and test set-up of wall W1 tested under ISO-fire exposure.

In addition to the fire tests on walls, a large-scale fire test on a loaded timber slab has recently been performed on EMPA's horizontal furnace $(3.0 \mathrm{x} 4.85 \mathrm{~m})$ with the objective to verify the results of the fire tests on combustible and non combustible claddings performed on the small furnace [14]. The timber slab consisted of solid timber beams with dimensions of $120 \times 260 \mathrm{~mm}$ and $60 \times 260 \mathrm{~mm}$. The cavities were partially filled with glass fibre and rock fibre insulation. The combustible claddings consisted of $27 \mathrm{~mm}$ thick 3-layered timber panels and OSB. The 3-layered timber panels made of spruce had a mean density of $341 \mathrm{~kg} / \mathrm{m}^{3}$ and an average moisture content of $11 \%$. The adhesive used for bonding of the 3-layered timber panels was the same polyurethane adhesive as for the timber panels used for the small-scale fire tests. Figure 9 shows the cross-section of the timber slab tested under ISO-fire exposure.

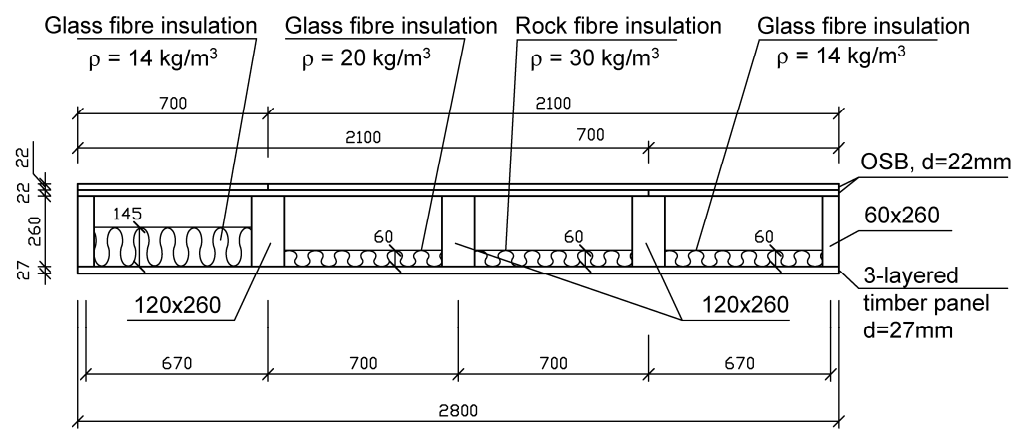

Fig. 9. Cross-section of the timber slab tested under ISO-fire exposure. 
The test results permit the analysis of the behaviour of the 3-layered timber panels (with $3 \times 9 \mathrm{~mm}$ thick layers). Table 4 gives the measured charring rate of the 3-layered timber panels exposed to ISO-fire. The charring rate was calculated based on the average temperature measurement on the fire unexposed side of the 3-layered timber panels. It was assumed that the 3-layered timber panel was completely charred, when the temperature on the fire unexposed side reached $300^{\circ} \mathrm{C}$.

Table 4. Measured charring rates for the $27 \mathrm{~mm}$ thick 3-layered timber panels of walls $\mathrm{W} 1, \mathrm{~W} 2$ and $\mathrm{W} 4$ as well as the timber slab.

\begin{tabular}{|c|c|c|c|}
\hline Test & $\begin{array}{c}\text { Thickness of 3-layered } \\
\text { timber panel [mm] }\end{array}$ & $\begin{array}{c}\mathbf{t}_{\mathbf{3 0}}{ }^{\circ} \mathbf{C} \text { measured on fire } \\
\text { unexposed side of panel [min] }\end{array}$ & $\begin{array}{c}\text { Charring rate } \boldsymbol{\beta} \\
\text { [mm/min] }\end{array}$ \\
\hline Wall W1 & 27 & 34.8 & 0.78 \\
\hline Wall W2 & 27 & 34.8 & 0.78 \\
\hline Wall W4 & 27 & 36.3 & 0.74 \\
\hline Timber slab & 27 & 27.3 & 0.99 \\
\hline
\end{tabular}

The measured charring rate of the $27 \mathrm{~mm}$ thick 3-layered timber panel of the timber slab was about 1.0 $\mathrm{mm} / \mathrm{min}$ confirming the results of the small-scale fire tests (see Table 3 ) and the FE-thermal analysis (see figure 7 right). During the fire test with the timber slab it was possible to observe a pronounced falling of the charred layers of the 3-layered timber panel as the fire progresses. The measured charring rate of the 27 $\mathrm{mm}$ thick 3-layered timber panels during the fire tests on walls varied between 0.74 und $0.78 \mathrm{~mm} / \mathrm{min}$. Falling of the charred layers of the 3-layered timber panels was less pronounced for the walls than for the slab. For this reason the measured charring rate of the 3-layered timber wall panels was smaller than in the case of the fire test on the timber slab. It can be concluded that vertical multi layered timber panels (walls) may show a better fire behaviour in comparison to horizontal timber panels (slabs) due to a less pronounced falling of the charcoal.

\section{Fire tests on cross-laminated solid timber panels (CNR-IVALSA)}

An extensive research project called SOFIE on the structural behaviour of cross-laminated solid timber panels is currently carried out at the Trees and Timber Institute CNR-IVALSA. The research project aims at supplying documentation and information on the use of cross-laminated solid timber panels as structural elements, in order to increase its use in particular for residential multi-storey buildings. One area of research of the SOFIE project focuses on the experimental analysis of the fire performance of crosslaminated solid timber panels. Two fire tests have been performed on unloaded walls made of crosslaminated solid timber panels at CNR-IVALSA's vertical furnace $(2 \times 2 \mathrm{~m})$ in San Michele all'Adige using ISO-fire exposure. Further, in order to analyze the global behaviour of timber structures made of crosslaminated solid timber panels a natural full-scale fire test on a 3 storey timber building has recently been carried out at the Building Research Institute in Tsukuba, Japan [15].

Table 5. Measured charring depth and charring rate for the fire tests with cross-laminated timber walls.

\begin{tabular}{|c|c|c|c|c|}
\hline Wall & Panel configuration & Fire time $[\mathbf{m i n}]$ & $\mathbf{d}_{\text {char }}[\mathbf{m m}]$ & $\beta[\mathbf{m m} / \mathbf{m i n}]$ \\
\hline P1 & $5 \times 17 \mathrm{~mm}=85 \mathrm{~mm}$ & 66 & 42.5 & 0.64 \\
\hline P2 & $3 \times 28 \mathrm{~mm}=84 \mathrm{~mm}$ & 39 & 26.5 & 0.68 \\
\hline
\end{tabular}

The walls tested consisted of cross-laminated solid timber panels made of spruce with $5 \times 17 \mathrm{~mm}$ thick layers (wall P1) and $3 \times 28 \mathrm{~mm}$ thick layers (wall P2), respectively. The adhesive used for bonding of the crosslaminated solid timber panels was a polyurethane adhesive, however it was not the same type as for the timber panels used in the small-scale fire tests. Figure 10 shows the wall P1 before and after the fire test. Table 5 gives the measured average charring depths and the resulting charring rates of the fire tests. The measured charring rates varied between 0.64 and $0.68 \mathrm{~mm} / \mathrm{min}$ and agree with the one-dimensional charring for homogeneous solid timber panels. For wall P2 an increased charring rate due to falling of charred layers was not expected as the fire test was stopped before the first layer of the cross-laminated solid timber panel was completely charred. For wall P1 an increased charring rate due to falling of the first and second charred layers was not observed. From Fig. 10 right it can be seen that after the fire test most of the charcoal of the first charred layer of the cross-laminated solid timber panel did not fall off. The fire tests 
confirmed that vertical multi layered timber panels (walls) may show a better fire behaviour in comparison to horizontal timber panels (slabs) due to a less pronounced falling of the charcoal. However, the analysis of these fire tests is still ongoing.
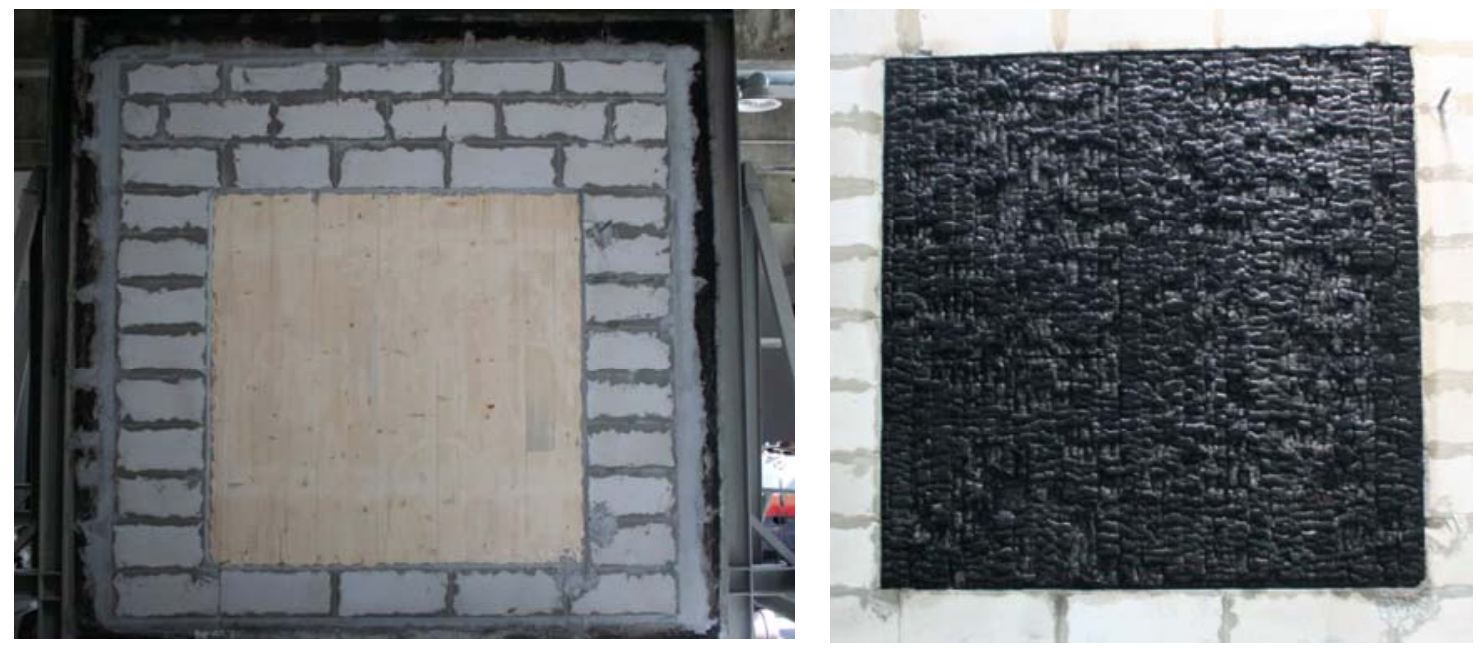

Fig. 10. Side of wall P1 not exposed to fire (left) and fire-exposed side of wall P1 after the fire test.

The results of a series of oven tests carried out to study the shear behaviour of different adhesives at high temperatures showed that the behaviour of polyurethane adhesives strongly depends on the type of adhesive [16]. Test results based on one particular polyurethane adhesive are therefore not valid for other polyurethane adhesives. Thus, the different adhesives used in the panels further may explain the differences observed between the tests of CNR-IVALSA and ETH Zurich.

\section{CONCLUSIONS}

The results of a FE-thermal analysis have shown that the fire behaviour of cross-laminated solid timber panels depends on the behaviour of the single layers. If the charred layers fall off, an increased charring rate needs to be taken into account. The same effect is observed for initially protected timber members after the fire protection has fallen off. Thus, the fire behaviour of cross-laminated solid timber panels can be strongly influenced by the thickness and the number of layers.

Fire tests carried out at the EMPA's horizontal furnaces showed that the charred layers of 3-layered timber panels fell off earlier than in the case of homogeneous timber panels. Thus, the measured charring rate of 3layered timber panels was higher than for homogeneous timber panels. Further the timber panel with $3 \times 9 \mathrm{~mm}$ thick layers showed a higher charring rate than the timber panel with $3 \times 18 \mathrm{~mm}$ thick layers, confirming that the fire behaviour of multilayer timber panels is strongly influenced by the thickness and the number of the layers in the case that the charcoal falls off after each layer is completely charred.

During fire tests carried out at the EMPA's vertical furnace a less pronounced falling of the charred layers of 3-layered timber panels was observed, leading to smaller charring rates in comparison to fire tests conducted on the horizontal furnaces. Fire tests on cross-laminated solid timber panels performed at CNRIVALSA's vertical furnace did not show falling of charred layers and the measured charring rates well agreed with the one-dimensional charring for homogeneous solid timber panels. Thus, vertical structural members (walls) may show a better fire behaviour in comparison to horizontal members (slabs) due to a less pronounced falling of the charred layers. Further, the behaviour of the bonding adhesive at high temperature can influence the falling of the charred layers and thus play an important role in the evaluation of the fire behaviour of multilayer timber panels.

The calculation of the charring depth of cross-laminated solid timber panels should take into account the influence of the falling of charred layers as well as the influence of longitudinal and transverse joints, for example by assuming a notional charring rate $\beta_{\mathrm{n}}$ that is higher than the one-dimensional charring rate $\beta_{0}$. Additional investigations are planned in order to extend and confirm the results of the experimental and numerical analyses performed. 


\section{REFERENCES}

[1] EN 1995-2 (Eurocode 5): Design of timber structures, Part 2: Bridges, CEN, Brüssel, 2004

[2] Buchanan, A.H., (2000) Fire performance of timber construction, Progress in Structural Engineering and Materials 278-289, doi:10.1002/1528-2716(200007/09)2:3<278::AID-PSE33>3.0.CO;2-P

[3] Young, S.A. and Clancy, P., (2001) Structural modelling of light-timber framed walls in fire, Fire Safety Journal 36: 241-268, doi:10.1016/S0379-7112(00)00053-9

[4] Frangi, A. and Fontana, M., (2003) Charring rates and temperature profiles of wood sections, Fire and Materials 27: 91-102, doi:10.1002/fam.819

[5] EN 1995-1-2 (Eurocode 5): Design of timber structures, Part 1-2: General - Structural fire design, CEN, Brüssel, 2004

[6] König, J. and Walleij, L., "Timber frame assemblies exposed to standard and parametric fires, Part 2: A design model for standard fire exposure", Trätek - Swedish Institute for Wood Technology Research. Report I 0001001, Stockholm, 2000

[7] König, J., (2005) Structural fire design according to Eurocode 5 - Design rules and their background, Fire and Materials 29: 147-163, doi:10.1002/fam.873

[8] Kordina, K. and Meyer-Ottens, C., Holz Brandschutz Handbuch, Deutsche Gesellschaft für Holzforschung e.V., München, 1994

[9] EN 1991-1-2 (Eurocode 1): Actions on Structures - Part 1-2: General Actions - Actions on Structures Exposed to Fire, CEN, Brüssel, 2002

[10] König, J. and Walleij, L., "One-dimensional charring of timber exposed to standard and parametric fires in initially protected and non-protected fire situations", Trätek - Swedish Institute for Wood Technology Research, Report No. I 9908029, Stockholm, 1999

[11] Erchinger, C., Frangi, A. and Mischler, A. Thermal investigations on multiple shear steel-totimber connections, Proceedings of $9^{\text {th }}$ World Conference on Timber Engineering (WCTE), Portland, USA, August 6-10, 2006.

[12] Schleifer, V., Frangi, A. and Fontana, M., "Experimentelle Untersuchungen zum Brandverhalten von Plattenelementen", IBK-testing report no. 302, Institute of Structural Engineering (IBK), ETH Zurich, 2007

[13] Fontana, M., Frangi, A. and Fetz, C., "Brandversuche an Holzmodulwänden", IBK-testing report no. 238, Institute of Structural Engineering (IBK), ETH Zurich, 1999

[14] Frangi, A., Schleifer, V. and Fontana, M., "Brandversuch an einer mit ISOVER Glaswolle Ultimate gedämmten belasteten Holzdecke", Testing report no. 2007-01, Institute of Structural Engineering (IBK), ETH Zurich, 2007

[15] Frangi, A., Bochicchio, G., Ceccotti, A. and Lauriola M.P., Natural Full-Scale Fire Test on a 3 Storey XLam Timber Building, Proceedings of $10^{\text {th }}$ World Conference on Timber Engineering (WCTE), Miyazaki, Japan, June 2-5, 2008.

[16] Frangi, A., Fontana, M. and Mischler, A. (2004) Shear behaviour of bond lines in glued laminated timber beams at high temperatures, Wood Science and Technology 38: 119-126, doi:10.1007/s00226-004-0223-y 